\title{
CD4/CD8 RATIO AS A PREDICTOR FOR THE OCCURRENCE OF METABOLIC SYNDROME IN HIV/AIDS PATIENTS DURING 6 MONTHS OF CART THERAPY
}

\author{
ODNOS CD4/CD8 KAO PREDIKTOR POJAVE METABOLIČKOG SINDROMA \\ KOD PACIJENATA SA HIV-OM/AIDS-OM TOKOM 6 MESECI CART TERAPIJE
}

\author{
Refet Gojak1, Vesna Hadžiosmanović1, Rusmir Baljić1, Lamija Zečević ${ }^{2}$ Jozo Ćorić3 , Željko Mijailović4 \\ ${ }^{1}$ University Clinical Centre Sarajevo, Clinic for Infectious Diseases, Sarajevo, Bosnia and Herzegovina \\ ${ }^{2}$ University Clinical Centre Sarajevo, Department of Immunology, Sarajevo, Bosnia and Herzegovina \\ ${ }^{3}$ University Clinical Centre Sarajevo, Department of Clinical Biochemistry, Sarajevo, Bosnia and Herzegovina \\ ${ }^{4}$ University of Kragujevac, Serbia, Faculty of Medical Sciences, Department of Infectious Diseases
}

\section{Summary}

Background: HIV infection is characterized by progressive depletion of $\mathrm{CD}^{+}{ }^{+} \mathrm{T}$ cells due to their reduced synthesis and increased destruction followed by marked activation and expansion of $\mathrm{CD}^{+} \mathrm{T}$ lymphocytes. CD4/CD8 ratio was traditionally described as a marker of immune system ageing in the general population, but it increasingly appears as a marker of different outcomes in the HIV-infected population. The main objective of this study is to examine the power of $C D 4 / C D 8$ ratio in predicting the occurrence of metabolic syndrome (MetS) in HIV-positive patients receiving CART therapy.

Methods: 80 HIV/AIDS subjects were included in a retrospective case-control study. Flow cytometry was used to determine the percentage of $\mathrm{CD}^{+}$and $\mathrm{CD} 8^{+}$cells in peripheral blood of these patients. The values of biochemical parameters (triglycerides, HDL, blood sugar, blood counts), immunological parameters (CD4/CD8, PCR), anthropometric measurements and type of cART therapy were evaluated in this study.

Results: After six months of cART therapy 19 (23.8\%) subjects had all the elements necessary for making the diagnosis of MetS. Using multivariate analysis CD4/CD8 ratio was statistically significant $(p<0.05)$ and had the largest effect on development of MetS (Wald = 9.01; OR = $0.45)$, followed by cART (Wald = 7.87; OR =0.10) and triglycerides (Wald $=5.27$; OR $=1.7$ ). On the other hand,

\section{Kratak sadržaj}

Uvod: HIV-infekcija se karakteriše progresivnim gubitkom $\mathrm{CD}^{+}{ }^{+}$T-ćelija zbog njihove smanjene sinteze, povećanog uništavanja i izrazite aktivacije i ekspanzije $C D 8^{+} \mathrm{T}$ limfocita. Količnik CD4/CD8 je tradicionalno opisivan kao marker imunostarenja u opštoj populaciji, ali se sve više pojavljuje kao marker različitih ishoda kod HIV-inficiranih pojedinaca. Osnovni cilj istraživanja je da se ispita kolika je moć CD4/CD8 količnika da predvidi nastanak metaboličkog sindroma kod HIV pozitivnih pacijenata koji primaju cART terapiju.

Metode: U retrospektivnoj studiji slučaj/kontrola je bilo uključeno $80 \mathrm{HIV/AIDS}$ ispitanika. Za određivanje udela (procenta) $\mathrm{CD}^{+}{ }^{+} \mathrm{i} \mathrm{CD}^{+}$ćelija iz periferne krvi pacijenata, korišćena je metoda protočne citometrije. $U$ ovoj studiji evaluirane su vrednosti biohemijskih parametara (trigliceridi, HDL, šećer u krvi, KS), imunoloških parametara (CD4/CD8, PCR), antropometrijska merenja, te vrsta cART. Rezultati: Nakon 6 meseci cART terapije 19 (23,8\%) ispitanika je ispunjavalo sve kriterijume za postavljanje dijagnoze MS. Multivarijantnom analizom statistički značajan ( $p<$ $0,05)$ i najveći uticajan na razvoj MS je imao količnik CD4/CD8 (Wald = 9,01; OR $=0,45$ ), potom cART (Wald $=7,87 ; \mathrm{OR}=0,10$ ), i na kraju trigliceridi (Wald $=5,27$; OR = 1,7). S druge strane, telesna težina i obim struka nisu pokazali statistički značajan uticaj na razvoj MS nakon šest meseci cART, $p>0,05$.

Address for correspondence:

Refet Gojak

Clinic for Infectious Diseases,

University Clinical Centre Sarajevo,

25 Bolnička Street, Sarajevo, Bosnia and Herzegovina

phone: +387 33297 25; Fax: +387 33297019

e-mail: refetmd@gmail.com 
body weight and waist circumference showed no statistically significant effect on the development of MetS after six months of cART, $p>0.05$.

Conclusions: $C D 4 / C D 8$ ratio proved to be a significant marker for prediction of metabolic syndrome in HIV/AIDS patients.

Keywords: HIV/AIDS, metabolic syndrome, CD4/CD8 ratio, cART

\section{Introduction}

HIV (human immunodeficiency virus) is a retrovirus which infects immune cells, especially $\mathrm{CD}^{+}{ }^{+} \mathrm{T}$ lymphocytes, and leads to progressive decay of these cells. CD4 cell count is used as a measure of immune function, and a lower CD4 cell count points to a weaker immune system (1). The reduction of $\mathrm{CD}^{+}{ }^{+} \mathrm{T}$ lymphocytes after HIV infection has several explanations, one of which is that frequent infections in these patients lead to chronic activation of $\mathrm{T}$ lymphocytes that ends with their apoptosis in a process called activation-induced cell death. The t-cell loss is the most reliable indicator of disease progression (2). However, not all T-cell subpopulations are deteriorated. HIV-infection is characterized by progressive $\mathrm{CD}^{+}{ }^{+}$T-cell deficiency due to reduced synthesis and increased cell death, but with marked activation and expansion of the $\mathrm{CD}^{+}$T-cell compartment (3). $C D 4^{+} \mathrm{T}$ lymphocytes are helper lymphocytes because they excrete cytokines that can activate other immune cells. CD8 lymphocytes are also called cytotoxic because they directly destroy virus-infected cells or tumour cells. CD4 lymphocytes are further divided into two subgroups, TH1 lymphocytes which excrete interleukin 2 (IL-2) and interferon gamma that can activate macrophages and natural killer (NK) cells, and TH2 lymphocytes which excrete IL-4, IL-5 and IL-10 that induce a humoral immune response (4).

Early treatment reduces the duration of high viremia exposure. New guidelines for treatment commencement recommend beginning treatment in case of symptomatic primary infection or at low $\mathrm{CD}^{+}$ count (5).

Combination antiretroviral therapy (cART) is recommended for all HIV infected persons in order to reduce the risk of disease progression and virus resistance to certain drugs. The primary goal of cART is to prevent HIV-related diseases and mortality, and the secondary goal is to reduce the risk of HIV transmission $(6,7)$. It is important to point out that cART leads to a significant reduction in some immune activation markers, but they are still significantly increased compared to uninfected controls (8). Although cART has dramatically increased the survival of patients with HIV infection, it can lead to several persistent metabolic abnormalities. However, data on the incidence of metabolic
Zaključak: Količnik CD4/CD8 se pokazao se kao značajan marker u predikciji metaboličkog sindroma kod HIV/AIDS pacijenata.

Ključne reči: HIV/AIDS, metabolički sindrom, odnos CD4/CD8, cART

syndrome (MetS) in persons infected with HIV vary considerably in various observational studies (9). MetS is a complex condition characterized by physical and metabolic abnormalities, which include central obesity, increased blood pressure, dyslipidemia and hyperglycemia (10).

At the beginning of studying HIV, it was suggested that besides viremia, the parameters of immunity activation such as CD8 lymphocytes, CD4/CD8 ratio or CD4 and CD8 lymphocyte percentage should be followed (11).

The CD4/CD8 ratio was traditionally described as an immunostimulatory marker in the general population but it increasingly appears as a marker of interest in HIV-infected individuals because it has been shown to identify individuals with persistent immune dysfunction that are at higher risk for nonAIDS events (such as MetS) and mortality despite the normalization of CD4 counts during therapy. Early CART has been found to be associated with a faster increase in $\mathrm{CD}^{+}$counts, as well as an increase in CD4/CD8 ratio (8). Lower CD4/CD8 ratio is also associated with increased morbidity and mortality of diseases not primarily related to HIV (12).

This study aims to examine the extent to which the CD4/CD8 ratio can predict the occurrence of metabolic syndrome in HIV-positive non-treated patients receiving CART therapy.

\section{Materials and Methods}

\section{Patients}

$80 \mathrm{HIV} / \mathrm{AIDS}$ subjects of both genders were included in a retrospective case-control study. Data was obtained from histories of HIV/AIDS patients who were hospitalized at the Clinic for Infectious Diseases of Clinical Center of the University of Sarajevo in the period from 2008-2018. Inclusion criteria for patients were: HIV/AIDS patients, aged > 18 years, both genders, which had not previously been treated with antiretroviral therapy. Criteria for exclusion from the study were: subjects who at the time of therapy commencement had 3 or more criteria for MetS, an active opportunistic disease or severe infectious disease, acute or chronic inflammatory disease, hypothyroidism, Cushing's syndrome, acute or chronic kidney disease, acute or 
chronic hepatitis, liver cirrhosis or pregnancy. All HIV/AIDS patients treated in the clinic above during the study period were included in the study if they met inclusion criteria (and did not meet the criteria for exclusion) to avoid selection bias.

Metabolic syndrome diagnosis was established if the patients met at least 3 out of the following 5 criteria: waist circumference over $94 \mathrm{~cm}$ in men, or over $80 \mathrm{~cm}$ in women; increased blood pressure (systolic $\geq 130 \mathrm{~mm} \mathrm{Hg}$ and/or diastolic $85 \mathrm{~mm} \mathrm{Hg}$ ); elevated triglyceride levels $(\geq 1.7 \mathrm{mmol} / \mathrm{L})$, reduced levels of high-density lipoprotein (HDL) (< 1.03 $\mathrm{mmol} / \mathrm{L}$ in men and $<1.29 \mathrm{mmol} / \mathrm{L}$ in women); and elevated fasting glucose levels ( $\geq 5.6 \mathrm{mmol} / \mathrm{L}$ ) (13).

The following data was taken from the medical histories of patients: age, sex, habits, HIV transmission mode, anthropometric measurements, values of biochemical parameters (triglycerides, HDL, blood sugar, blood count), immunological parameters (CD4/CD8, PCR), and type of cART therapy. Immunological laboratory parameter measurements of this study were part of the usual treatment of patients with HIV infection.

\section{Immunophenotyping of lymphocytes}

In the test tube with the anticoagulant EthyleneDiamino-Tetra-Acetate (Vacutainer Tubes with K3EDTABecton Dickinson, Plymouth, United Kingdom) for immunophenotyping lymphocyte profiles using the method of flow cytometry, patients full-blood was treated with monoclonal antibodies (FITC, PE, PerCP, APC) (Table I) to determine the expression of certain cellular receptors within 48 hours upon receiving the sample and according to the manufacturer's protocol (BD Biocsience, San Jose, CA, USA and BD Pharmigen, San Diego, CA, USA) at the Department of Clinical Immunology of Clinical Centre of University of Sarajevo.

In the analyzed sample lymphocytes were defined via the gating method by size and cell granulation (FSC vs SSC). After that, lymphocyte subpopulations were determined by fluorescence on

Table I Combination of monoclonalantibodies.

\begin{tabular}{|l|l|l|l|l|}
\hline & FITC & PE & PerCP & APC \\
\hline Tube 1 & CD3 & CD8 & CD45 & CD4 \\
\hline Tube 2 & CD3 & CD15+56 & CD45 & CD19 \\
\hline
\end{tabular}

FITC - Fluorescein isothiocyanate, PE - Phycoerythrin, PerCP - Peridinin Chlorophyll Protein Complex, APC Allophycocyanin, CD - cluster of differentiation. dual-parameter histograms. In each sample, 10,000 cells were analyzed, and the results were expressed as the percentage (proportion) of the examined cells in each subpopulation of lymphocytes. Cell subpopulations were analyzed in the DIVA program, version 6.1.3 (DB Bioscience, San Jose, CA, USA). The absolute number of individual subpopulations (the number of cells per $1 \mathrm{~mL}$ of blood) was determined by the formula:

Abs CD4 (CD8) = WBC $\times$ Lym/100 x (\% positive cells Cd4 or CD8)/100

\section{Ethics}

The research was approved by the Ethics Committee of the University Clinical Center of Sarajevo and implemented according to the basic principles of the Helsinki Declaration (last version of 2008) on the rights of patients involved in biomedical research.

\section{Statistical analysis}

The statistical analysis of data was done using a licensed statistical program for Windows (version 19.0, SPSS Inc., Chicago, Illinois, USA) and Microsoft Excel (version 11 of Microsoft Corporation, Redmond, WA, USA). The collected data was analyzed at the level of descriptive statistics with central tendency measures (arithmetic mean and median) and variance measures (standard deviation and standard error). Considering the normal distribution of continuous variables, which was proved by the Kolmogorov-Smirnov test, we used the Independent Samples T-test to calculate the significance of differences between this data. Univariate binary logistic regression investigated the individual influence of independent variables on the binary dependent variable MetS (yes/no) after six months of CART therapy. Multivariate binary regression analysis investigated the effect of independent predictors (model 1) that demonstrated in the univariate analysis significant influence on the dependent variable MetS (yes/no) after 6 months of cART therapy. All analyses were evaluated at a level of statistical significance of $p<0.05$. After statistical processing of data, results were presented in tables.

\section{Results}

The study included 80 HIV/AIDS subjects: 72 (90\%) men and $8(10 \%)$ women. The age of subjects at the time they were tested and detected with HIV/AIDS for men was $34.3 \pm 8.5$ years and $38.6 \pm$ 11.1 years for women. Smokers were less represented (33 or $41.3 \%$ ) compared to non-smokers (47 or $58.8 \%)$. The majority of subjects were not exintravenous (IV) drug users (70; 87.5\%), while 10 
$(12.5 \%)$ subjects were. MSMs (men who have sex with men) dominate with 49 subjects (61.3\%), 30 $(37.5 \%)$ subjects were heterosexual, and one subject $(1.2 \%)$ was without clear sexual orientation.

After 6 months of ART therapy the values of CD4/CD8 ratio increased significantly to $0.51 \pm$ 0.35 ( $p=0.0001)$. Out of all $n=80$ subjects 19 (23.8\%) developed MetS, and 61 (76.3\%) did not. Metabolic syndrome was developed by 11 of 29 subjects or $37.9 \%$ on PI + NRT therapy, and 8 out of 51 subjects or $15.6 \%$ on NNRT + NRT therapy. Subjects who developed MetS after 6 months of therapy had mean values of waist circumference for men $(94.8 \pm 3.5 \mathrm{~cm})$, and women $(89.0 \pm 28 \mathrm{~cm})$; triglyceride levels of $3.6 \pm 1.9$; fasting glucose levels of $5.6 \pm 0.9$; systolic pressure levels of $130.5 \pm$ 16.4; diastolic levels of $82.3 \pm 7.5$; HDL levels for men $(0.84 \pm 0.20)$, and women (1.11 \pm 0.02$)$.
Using univariate binary logistic regression, the individual influence of independent variables on the development of MetS (yes/no) after six months of cART therapy was investigated. The most statistically significant individual influence $(p<0.05$ ) according to Wald coefficients has been shown by the following variables:

The CD4 percentage before the onset of therapy has the individual strongest influence (Wald = 9.03; OR $=0.87$ ) along with CD4/CD8 ratio (Wald $=6.56, \mathrm{OR}=0.58)$. This is followed by triglycerides (Wald $=6.4, \mathrm{OR}=1.89$ ), waist circumference (Wald = 4.8; OR = 1.14), cART (Wald = 4.8; OR = 0.30) and body weight (Wald $=4.5, \mathrm{OR}=1.05)$. Other variables (gender, age, smoking status, height, BMI, systolic and diastolic pressure, CD8\%, RNA PCR, $\mathrm{HDL}$, fasting glucose and blood count elements) were not of significant influence (Table II).

Table II Univariate binary logistic regression.

\begin{tabular}{|c|c|c|c|c|c|c|c|c|}
\hline \multirow[b]{2}{*}{ Variable } & \multirow[b]{2}{*}{$B$} & \multirow[b]{2}{*}{ S.E. } & \multirow[b]{2}{*}{ Wald } & \multirow[b]{2}{*}{$\mathrm{df}$} & \multirow[b]{2}{*}{$p$} & \multirow[b]{2}{*}{ OR } & \multicolumn{2}{|c|}{ 95.0\% C.I.for OR } \\
\hline & & & & & & & Lower & Upper \\
\hline Gender (M/F) & -0.847 & 1.103 & 0.590 & 1 & 0.442 & 0.429 & I & / \\
\hline Age (years) & 0.035 & 0.029 & 1.44 & 1 & 0.229 & 1.035 & / & / \\
\hline Smoking status(yes/no) & 0.328 & 0.529 & 0.383 & 1 & 0.536 & 1.387 & / & I \\
\hline Height $(\mathrm{cm})$ & 5.956 & 3.813 & 2.440 & 1 & 0.118 & 386.144 & / & / \\
\hline Weight $(\mathrm{kg})$ & 0.050 & 0.023 & 4.51 & 1 & 0.034 & 1.051 & 1.009 & 1.100 \\
\hline BMI & 0.101 & 0.083 & 1.479 & 1 & 0.224 & 1.106 & / & l \\
\hline Waist circumference $(\mathrm{cm})$ & 0.133 & 0.060 & 4.84 & 1 & 0.028 & 1.142 & 1.015 & 1.285 \\
\hline Systolic pressure $(\mathrm{mmHg})$ & 0.052 & 0.038 & 1.901 & 1 & 0.168 & 1.054 & I & I \\
\hline Diastolic pressure $(\mathrm{mmHg})$ & -0.033 & 0.055 & 0.359 & 1 & 0.549 & 0.968 & I & I \\
\hline CD4 (\%) & -0.130 & 0.043 & 9.03 & 1 & 0.003 & 0.878 & 0.807 & 0.956 \\
\hline CD8 (\%) & -0.017 & 0.022 & 0.604 & 1 & 0.437 & 0.983 & I & I \\
\hline CD4/CD8 Ratio & -0.531 & 0.207 & 6.56 & 1 & 0.010 & 0.588 & 0.392 & 0.883 \\
\hline PCR RNA (log)cells/ml & 0.015 & 0.290 & 0.003 & 1 & 0.959 & 1.015 & / & l \\
\hline Triglycerides (mmol/L) & 0.638 & 0.252 & 6.40 & 1 & 0.011 & 1.894 & 1.155 & 3.105 \\
\hline $\mathrm{HDL}(\mathrm{mmol} / \mathrm{L})$ & -0.085 & 0.361 & 0.056 & 1 & 0.813 & 0.918 & / & / \\
\hline Erythrocytes $\times 10^{12} / \mathrm{L}$ & -0.214 & 0.307 & 0.486 & 1 & 0.486 & 0.808 & / & I \\
\hline Blood glucose (mmol/L) & 0.461 & 0.427 & 1.166 & 1 & 0.280 & 1.585 & / & I \\
\hline Leukocytes $\times 10^{9} / \mathrm{L}$ & 0.211 & 0.133 & 2.525 & 1 & 0.112 & 1.235 & l & I \\
\hline Lymphocytes \% & 0.756 & 2.031 & 0.139 & 1 & 0.710 & 2.131 & I & I \\
\hline Thrombocytes $\times 10^{9} / \mathrm{L}$ & 0.002 & 0.004 & 0.424 & 1 & 0.515 & 1.002 & I & I \\
\hline $\begin{array}{l}\text { cART(NNRTIs + NRTI } \\
\text { compared to PI + NRTI) }\end{array}$ & -1.189 & 0.543 & 4.79 & 1 & 0.028 & 0.304 & 0.105 & 0.882 \\
\hline
\end{tabular}

$\mathrm{CD}$ - cluster of differentiation, BMI - body mass index, HDL - high-density lipoprotein, CART - combined antiretroviral therapy, NNRTIs - Non-nucleoside reverse transcription inhibitors, NRTI - nucleoside reverse transcription inhibitors, PI - Protease inhibitors. 
Table III Multivariate binary logistic regression.

\begin{tabular}{|l|l|c|c|c|c|c|}
\hline \multicolumn{2}{|l|}{ Variable } & B & Wald & df & p. & OR \\
\hline Model 1 & Body weight (kg) & 0.020 & 0.164 & 1 & 0.686 & 1.020 \\
\hline & Waist circumference (cm) & 0.236 & $\mathbf{2 . 8 3 0}$ & 1 & 0.093 & 1.266 \\
\hline & Triglycerides (mmol/L) & 0.767 & $\mathbf{5 . 2 7 0}$ & 1 & 0.022 & 2.152 \\
\hline & CD4/CD8 ratio & -0.803 & $\mathbf{9 . 0 1 2}$ & 1 & 0.003 & 0.448 \\
\hline & $\begin{array}{l}\text { CART(NNRTIs+NRTI compared } \\
\text { to PI+NRTI) }\end{array}$ & -2.249 & $\mathbf{7 . 8 6 6}$ & 1 & 0.005 & 0.106 \\
\hline & Constant & -27.197 & 6.240 & 1 & 0.012 & 0.0001 \\
\hline
\end{tabular}

CD - a cluster of differentiation, cART - combined antiretroviral therapy, NNRTIs - Non-nucleoside reverse transcription inhibitors, NRTI - nucleoside reverse transcription inhibitors, $\mathrm{PI}$ - Protease inhibitors.

Multivariate analysis of parameters (which proved to be significant in univariate regression analysis) yielded Model 1 where the values of Cox \& Snell $R^{2}=0.338$ and Nagelkerke $R^{2}=0.507$ show that the set of variables explain $33.8 \%$ to $50.7 \%$ of the variance. Further results of the Hosmer and Lemeshow test support the claim that the model is good, $2=19.910 \mathrm{p}=0.084$.

Surrogate marker CD4/CD8 ratio showed the most statistically significant $(p<0.05)$ and greatest influence on MetS development (Wald $=9.01$, OR = 0.45 ), followed by cART (Wald $=7.87$, OR $=0.10$ ), and triglycerides (Wald $=5.27 ; \mathrm{OR}=1.7$ ). In this analysis, body weight and waist circumference did not show a statistically significant effect on MetS development after six months of cART, $p>0.05$ (Table III).

\section{Discussion}

In our study, we have shown that the choice of cART drugs (NNRTIs + NRTI vs PI + NRTIs) and $C D 4 / C D 8$ ratio have a protective effect on the occurrence of MetS in patients with HIV/AIDS, while larger waist circumference and triglyceride levels at the beginning of therapy increase the risk of MetS development.

ART therapy has been available in Bosnia and Herzegovina (B\&H) since 2003. The choice of cART depends on the CD4 count, viremia, HIV resistance, adherence prognosis, comorbidities, adverse drug effects, interaction with other drugs, as well as the cost of the drug itself. Due to the realistically low number of HIV infected, some ART drugs could not be registered in $\mathrm{B} \& \mathrm{H}$ (due to high price of drug registration and low consumption); therefore we had a smaller amount of drugs on disposition compared to the $\mathrm{EU}$, the price of some drugs was very expensive for a country such as $B \& H$, and we were forced to choose more affordable and available medicines.
The real prevalence of MetS among HIV-positive patients is still controversial due to a large number of observational studies with a wide range of prevalence estimates (from 7 to $52 \%$ ). It is difficult to determine whether the prevalence of MetS in HIV-infected patients is different or comparable with the prevalence in the general population (14).

Due to the effectiveness of modern HIV/AIDS therapy, lifespan with this disease is prolonged. Physicians are now facing new challenges in treating comorbidities, such as MetS. Even so, the prevalence of MetS in patients with HIV is not the same as in the general population (15).

In one study (9) the prevalence of MetS in the study population was $16 \%$ for the International Diabetes Federation (IDF) definition. Prevalence of MetS was significantly higher among patients receiving cART therapy than among HIV therapy-naive patients (18.2\% vs 5.1\%, p =0.005) (9).

Another study (16) shows that the MetS prevalence in subjects on ART was higher (18.4\%) compared to subjects who were not on ART (11.8\%). In comparison, our study showed that 19 out of 80 subjects or $23.8 \%$ developed MetS after six months of cART.

Earlier research has already demonstrated the relationship between combination ART therapy and dyslipidemia, insulin resistance and cardiovascular disease (CVD), as well as poor adherence of HIV+ subjects on PI inhibitors (17).

A study by Perazzo (18) clearly showed that low CD4 counts $(<200$ cells $/ \mathrm{ml})$ with $\mathrm{OR}=50.7$ present a risk for MetS development (18), whereas our study also showed the risk of MetS development with low CD4\% (OR $=0.87, \mathrm{p}=0.003)$.

In one study (19) on HIV-infected individuals treated within 6 months of HIV detection compared to two years after seroconversion, the CD4/CD8 ratio 
remained low and did not normalize in the group being treated immediately upon detection of HIV infection (19). Contrary to their results, Hoenigli et al. (20) found that CD4/CD8 ratio was lower in individuals with symptomatic acute HIV infection and that it correlated with the duration of acute HIV infection symptoms. Early ART (initiated within 40 days from the estimated date of infection) has shown to be associated with a significant increase in CD4/CD8 ratio (20).

Their data suggests that the CD4/CD8 ratio decreases rapidly during acute HIV infection, but can be significantly increased when ART is commenced, as we have demonstrated in our study where 6 months after ART therapy the CD4/CD8 ratio increased from $0.29 \pm 0.21$ to $0.51 \pm 0.35(p=0.0001)$. Similar results were obtained by $\mathrm{Han} W M$ et al. (21) on a sample of 800 subjects, where the total reference CD4/CD8 ratio before ART was 0.22 (IQR, 0.12$0.32)$ and after achieving virological suppression this ratio was 0.42 (IRQ: 0.27-0.56) (21).

The same study showed that HIV-infected subjects with a CD4/CD8 ratio of $<0.3$, or in the range between 0.3 and 0.45 , had a significantly higher risk of non-AIDS disease development compared to HIV subjects with a ratio greater than 0.45 . Ultimately, our study also showed that the CD4/CD8 ratio was a significant univariate and multivariate predictor (together with triglycerides and $c A R T$ ) of non-AIDS disease and MetS ( $p<0.05)$.

Study SHSC (2016) showed that the CD4/CD8 ratio was an important time-dependent prognostic

\section{References}

1. HIV monitoring (2018). [Internet] Available at: https://www.hiv-monitoring.nl/english/patients-andpublic/about-hiv/ [accessed on October 12, 2018]

2. Abbass AK, Lichtman AH. Congenital and acquired immunodeficiency. In: Basic Immunology. Data Status, 2008: 209-23.

3. Masiá M, Padilla S, Barber X, Sanchis M, Terol G, Lidón F, Gutiérrez F. Comparative Impact of Suppressive Antiretroviral Regimens on the CD4/CD8 T-Cell Ratio: A Cohort Study. Medicine (Baltimore). 2016 and 95(11): e3108.

4. Luckheeram RV, Zhou R, Verma AD, Xia B (2012) CD4(+)T cells: differentiation and functions. Clinical \& developmental immunology 2012: 925135.

5. Seng R, Goujard C, Krastinova E, Miailhes P, Orr S, Molina JM, Saada M, Piroth L, Rouzioux C, Meyer L. Influence of lifelong cumulative HIV viremia on longterm recovery of $\mathrm{CD}^{+}$cell count and $\mathrm{CD} 4^{+} / \mathrm{CD}^{+}{ }^{+}$ratio among patients on combination antiretroviral therapy. Aids 2015 Mar 13; 29(5): 595-607.

6. Divakar DD, Al Kheraif AA, Ramakrishnaiah R, Khan AA, Sandeepa NC2, Alshahrani OA, Ali Alahmari A. Oral factor, for the treatment of HIV naive patients and patients treated with cART. Data from this study confirmed the association between HIV/AIDS disease progression and the time needed for normalization of the CD4/CD8 ratio $(22,23)$.

The limitations of our study were a relatively small sample and retrospective analysis, which is why data on physical activity, nutrition and other possible predisposing factors during the first 6 months of therapy are missing.

\section{Conclusions}

Clinicians should keep in mind the percentage of CD4 and low levels of CD4/CD8 ratio, along with other parameters of metabolic syndrome development (central obesity, high blood pressure, dyslipidemia, and blood sugar), when selecting CART drug regimens to reduce the prevalence of non-AIDS diseases or MetS. The results of this study should be considered as preliminary, while verification of these results requires new prospective epidemiological studies with greater statistical strength and follow-up of a wider range of factors that may have an impact on metabolic syndrome.

\section{Conflict of interest statement}

The authors stated that they have no conflicts of interest regarding the publication of this article.

manifestations in human immunodeficiency virus infected pediatric patients receiving and not receiving antiretroviral therapy: a cross sectional study. Paediatr Croat 2015; 59: 152-8.

7. Forsyth $A D$, Valdiserri RO. Reaping the prevention benefits of highly active antiretroviral treatment: policy implications of HIV Prevention Trials Network 052. Curr Opin HIV AIDS. 2012 and 7(2): 111-6.

8. Rajasuriar R, Wright E, Lewin SR. Impact of antiretroviral therapy (ART) timing on chronic immune activation/inflammation and end-organ damage. Curr Opin HIV AIDS. 2015 and 10(1): 35-42.

9. Calza L, Colangeli V, Magistrelli E, Rossi N, Rosselli Del Turco E, Bussini L, Borderi M, Viale P. Prevalence of metabolic syndrome in HIV-infected patients naive to antiretroviral therapy or receiving a first-line treatment. HIV clinical trials. 2017 May 4; 18(3): 110-7.

10. Puhalo Sladoje D, Kisić B, Mirić D. The monitoring of protein markers of inflammation and serum lipid concentration in obese subjects with metabolic. J Med Biochem 2017; 36: 366-74. 
11. Cohen Stuart JWT, Hazebergh MD, Hamann D, et al. The dominant source of $\mathrm{CD}^{+}$and $\mathrm{CD}^{+}{ }^{+}$T-cell activation in HIV infection is antigenic stimulation. J Acquir Immune Defic Syndr 2000 and 25: 203-11.

12. Mussini C, Lorenzini P, Cozzi-Lepri A, et al. CD4/CD8 ratio normalisation and non-AIDS-related events in individuals with HIV who achieve viral load suppression with antiretroviral therapy: an observational cohort study. Lancet HIV 2015 and 2: e98-e106.

13. Alberti KG, Eckel RH, Grundy SM, Zimmet PZ, Cleeman JI, Donato KA, Fruchart JC, James WP, Loria CM, Smith Jr SC. Harmonizing the metabolic syndrome: a joint interim statement of the international diabetes federation task force on epidemiology and prevention; national heart, lung, and blood institute; American heart association; world heart federation; international atherosclerosis society; and international association for the study of obesity. Circulation 2009 Oct 20; 120(16): 1640-5.

14. Mondy K, Overton ET, Grubb J, et al. Metabolic syndrome in HIV-infected patients from an urban, Midwestern US outpatient population. Clin Infect Dis 2007 and 44: 726-34.

15. Swami A. Metabolic Syndrome and HIV Infection. J HIV Retrovirus, 2016, 2: 1.

16. Nguyen KA, Peer N, Mills EJ, Kengne AP. A meta-analysis of the metabolic syndrome prevalence in the global HIVinfected population. PloS one. 2016 Mar 23 and 11(3): e0150970.

17. Anuurad E, Bremer A, Berglund L. HIV protease inhibitors and obesity. Curr Opin Endocrinol Diabetes Obes 2010 and 17(5): 478-85.
18. Perazzo H, Cardoso SW, Yanavich C, Munteanu M, Morata M, Simplicio P, Cardoso C, Almeida C, Poynard T, Veloso VG, Grinsztejn B. Presence of metabolic syndrome and low CD4 count are independently associated with liver fibrosis in human immunodeficiency virusinfected patients with non-alcoholic fatty liver. Journal of Hepatology 2017 Jan 1; 66(1): S158-9.

19. Serrano-Villar S, Sainz T, Lee SA, Hunt PW, Sinclair E, Shacklett BL, Ferre AL, Hayes TL, Somsouk M, Hsue PY, Van Natta ML. HIV-infected individuals with low CD4/CD8 ratio despite effective antiretroviral therapy exhibit altered $\mathrm{T}$ cell subsets, heightened $\mathrm{CD}^{+} \mathrm{T}$ cell activation, and increased risk of non-AIDS morbidity and mortality. PLoS pathogens 2014 May 15; 10(5): e1004078.

20. Hoenigl M, Chaillon A, Little SJ. CD4/CD8 Cell Ratio in Acute HIV Infection and the Impact of Early Antiretroviral Therapy. Clin Infect Dis 2016 and 63(3): 425-6.

21. Han WM, Apornpong T, Kerr SJ, Hiransuthikul A, Gatechompol S, Do T, Ruxrungtham K, Avihingsanon A. CD4/CD8 ratio normalization rates and low ratio as prognostic marker for non-AIDS defining events among long-term virologically suppressed people living with HIV. AIDS research and therapy. 2018 Dec; 15(1): 13.

22. Milinković N, Ignjatović S, Šumarac Z, Majkić-Singh N. Uncertainty of measurement in laboratory medicine. J Med Biochem 2018; 37: 279-88.

23. Sauter R, Huang $R$, Ledergerber $B$, Battegay $M$, Bernasconi $E$, Cavassini $M$, Furrer $H$, Hoffmann $M$, Rougemont M, Günthard HF, Held L. CD4/CD8 ratio and $C D 8$ counts predict CD4 response in HIV-1-infected drug naive and in patients on cART. Medicine 2016 Oct; 95 (42). 